\title{
Modeling Operational Parameters for Uranium Dioxide Production Reactor through Uranium Trioxide Reaction Using Hydrogen
}

\author{
Pedro Orrego ${ }^{1}$, José Hernández ${ }^{1}$, Jorge Manríquez ${ }^{2}$ \\ ${ }^{1}$ Sección de Geología y Minería, Departamento de Materiales Nucleares, Comisión Chilena de Energía Nuclear, \\ Santiago, Chile \\ ${ }^{2}$ Ingeniería Civil Metalurgia, Universidad de Santiago de Chile, Santiago, Chile \\ Email: porrego@cchen.cl, jjhernandez@cchen.cl,jorge.manriquez@usach.cl
}

Received 4 May 2016; accepted 6 July 2016; published 9 July 2016

Copyright @ 2016 by authors and Scientific Research Publishing Inc.

This work is licensed under the Creative Commons Attribution International License (CC BY).

http://creativecommons.org/licenses/by/4.0/

(c) (i)

\section{Abstract}

This article shows the modeling of a uranium dioxide production reactor using COMSOL Multiphysics software program in its $4.3 \mathrm{~b}$ version. The model was made using 3 kinds of studies: momentum, heat and mass transport, in order to determine the influence of the most important operational parameters: $\mathrm{UO}_{3}$ reaction rate, composition and flow of the reduction gas, the initial temperature reactor and the reducing gas. The operational parameters evaluated were the followings: constant gas flow of $2.5 \mathrm{~L} / \mathrm{min}$, initial hydrogen concentration of $0.25,0.50$ and $0.75 \mathrm{M}$, and initial temperature of $400^{\circ} \mathrm{C}$. The obtained results allow to conclude that under these working conditions, uranium dioxide is obtained virtually instantaneous and, with concentrations close to $0.5 \mathrm{M} \mathrm{H}_{2}$ in the reducing gas, the process can operate continuously and autogenously, without applying additional energy and temperatures around $600^{\circ} \mathrm{C}$.

\section{Keywords}

Uranium Trioxide, Uranium Dioxide, Conversion, Modeling

\section{Introduction}

Nuclear energy is a source of major electricity production, due to the high-energy capacity of the uranium fuel element during nuclear fission. Uranium is used mainly in the form of $\mathrm{UO}_{2}$ type compounds. For this purpose, it 
must be enriched in its $\mathrm{U}^{235}$ isotope to fulfill this purpose. The needed enrichment level will depend on the type of reactor used, and there are 2 types: Light Water Reactors (LWR), which require an enrichment of $\mathrm{U}^{235}$ minimum between 3 and 5\% to operate, and Pressurized Heavy Water Reactor (PHWR), which uses natural uranium as fuel [1].

Figure 1 shows the uranium conversion for the production of $\mathrm{UF}_{6}$, raw material for the enrichment process.

This process reduces the uranium compound, either from $\mathrm{UO}_{3}$ or from $\mathrm{U}_{3} \mathrm{O}_{8}$, and obtains $\mathrm{UO}_{2}$ powders, according to the overall reaction:

$$
\mathrm{UO}_{3}+\mathrm{H}_{2} \rightarrow \mathrm{UO}_{2}+\mathrm{H}_{2} \mathrm{O} .
$$

Subsequently, $\mathrm{UO}_{2}$ powder should be treated by hydrofluorination to obtain $\mathrm{UF}_{4}$ powders:

$$
\mathrm{UO}_{2}+4 \mathrm{HF} \rightarrow \mathrm{UF}_{4}+2 \mathrm{H}_{2} \mathrm{O} \text {. }
$$

Finally, the $\mathrm{UF}_{4}$ compound is taken to the fluorination process to obtain $\mathrm{UF}_{6}$ :

$$
\mathrm{UF}_{4}+\mathrm{F}_{2} \rightarrow \mathrm{UF}_{6} \text {. }
$$

The $\mathrm{UF}_{6}$ compound, gaseous at $56^{\circ} \mathrm{C}$ and atmospheric pressure, is carried to the enrichment process, in order to obtain a concentrated and a diluted fraction in $\mathrm{U}^{235}$ through centrifugal force reactors [3], using the different weights of this and the $\mathrm{U}^{238}$ isotope. This process is shown schematically in Figure 2 [4].

The gaseous compound $\mathrm{UF}_{6}$, once enriched, must return to its $\mathrm{UO}_{2}$ form. To do this, there are 3 methods to carry out this task [7] [8].

$\mathrm{H}_{2}$ reduction: The $\mathrm{UF}_{6(\mathrm{~g})}$ compound is reduced using hydrogen according to the reactions:

$$
\begin{gathered}
\mathrm{UF}_{6}+\mathrm{H}_{2} \rightarrow \mathrm{UF}_{4}+2 \mathrm{HF} \\
\mathrm{UF}_{4}+2 \mathrm{H}_{2} \mathrm{O} \rightarrow \mathrm{UO}_{2}+4 \mathrm{HF} .
\end{gathered}
$$

Hydrolyzing: The $\mathrm{UF}_{6(\mathrm{~g})}$ compound is hydrolyzed using water:

$$
\begin{gathered}
\mathrm{UF}_{6}+2 \mathrm{H}_{2} \mathrm{O} \rightarrow \mathrm{UO}_{2} \mathrm{~F}_{2}+4 \mathrm{HF} \\
2 \mathrm{UO}_{2} \mathrm{~F}_{2}+6 \mathrm{NH}_{4} \mathrm{OH} \rightarrow\left(\mathrm{NH}_{4}\right)_{2} \mathrm{U}_{2} \mathrm{O}_{7}+4 \mathrm{NH}_{4} \mathrm{~F}+3 \mathrm{H}_{2} \mathrm{O} .
\end{gathered}
$$

Subsequently, the ammonium diuranate is reduced using $\mathrm{H}_{2}$ at temperatures of $600^{\circ} \mathrm{C}-800^{\circ} \mathrm{C}$ :

$$
\left(\mathrm{NH}_{4}\right)_{2} \mathrm{U}_{2} \mathrm{O}_{7}+2 \mathrm{H}_{2} \rightarrow 2 \mathrm{UO}_{2}+2 \mathrm{NH}_{3}+3 \mathrm{H}_{2} \mathrm{O} \text {. }
$$

Finally, the third method for enriched $\mathrm{UO}_{2}$ production is through precipitation of ammonium uranyl carbonate instead of ammonium diuranate, according to reaction (10):

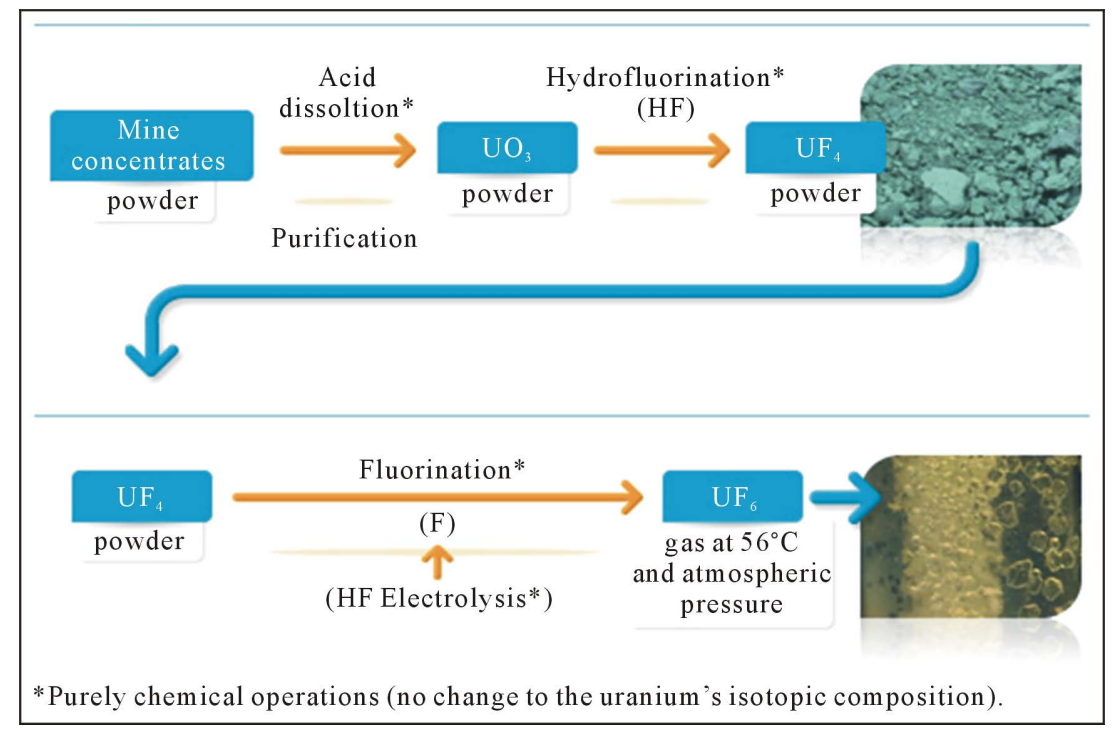

Figure 1. Uranium conversion process [2] [3]. 


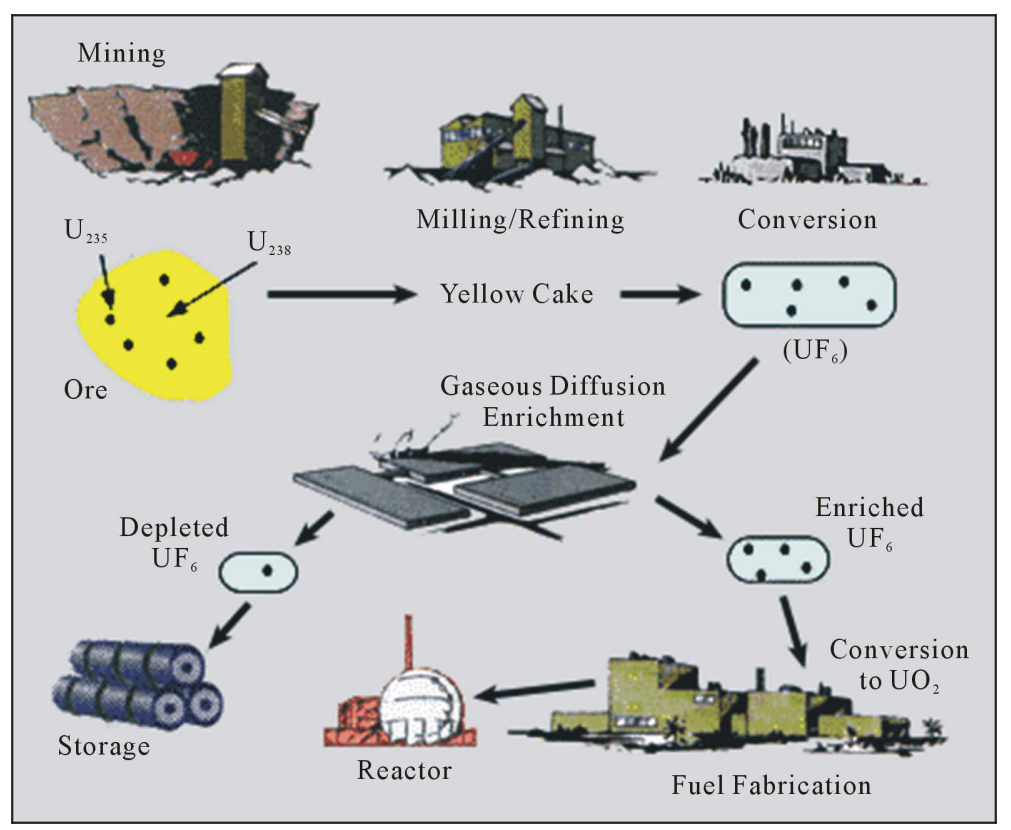

Figure 2. The process leading to obtain $\mathrm{UO}_{2}$ fuel elements [5] [6].

$$
2 \mathrm{UO}_{2} \mathrm{~F}_{2}+3 \mathrm{H}_{2} \mathrm{O}+6 \mathrm{NH}_{3}+3 \mathrm{CO}_{2} \rightarrow\left(\mathrm{NH}_{4}\right)_{4} \mathrm{UO}_{2}\left(\mathrm{CO}_{3}\right)_{3}+4 \mathrm{NH}_{4} \mathrm{~F} .
$$

All these processes require the use of a fluidized bed reactor for producing $\mathrm{UO}_{2}$ for both $\mathrm{UF}_{6}$ production, intended for further uranium enrichment, as for reproduction as $\mathrm{UO}_{2}$ fuel pellets for nuclear power reactors.

It is for these reasons that this work will evaluate the main operating parameters of a fluidized bed reactor for $\mathrm{UO}_{2}$ production from $\mathrm{UO}_{3}$ concentrates using mathematical modeling techniques and the COMSOL Multiphysics software, in its $4.3 \mathrm{~b}$ version. These parameters are the followings: feed flow, hydrogen concentration and initial temperature.

Conventional $\mathrm{UO}_{3}$ to $\mathrm{UO}_{2}$ reduction reactor is shown in Figure 3.

$\mathrm{UO}_{2}$ production is conventionally performed in a reduction reactor as shown in Figure 3. Here, uranium trioxide and hydrogen are continuously fed, $\mathrm{H}_{2}$ is normally diluted in an inert gas such as argon or nitrogen. It is also common to use ammonia, which is cracked [11] to obtain a nitrogen and hydrogen gas mixture. This $\mathrm{UO}_{2}$ production reactor [12] [13] is controlled by the following operational parameters: composition and flow of the reducing gas, $\mathrm{UO}_{3}$ feed and internal reactor temperature.

\section{Theoretical Basis [14]}

\subsection{Momentum Transport}

Momentum transport is given by the Navier-Stokes equation, for compressible fluids:

$$
\begin{gathered}
\rho(u \cdot \nabla) u=\nabla \cdot\left[-\rho I+\mu\left(\nabla u+(\nabla u)^{T}\right)\right]+F \\
\rho \nabla \cdot u=0
\end{gathered}
$$

where: $\rho$ : density, $u$ : $\mathrm{H}_{2}$ flow velocity, I: identity matrix, $F$ : External forces.

Momentum transport will determine the gas behavior inside the reduction reactor, for laminar regime.

\subsection{Heat Transport}

Heat transport is determined by the following equations:

$$
\rho C_{p} \frac{\partial T}{\partial x}+\rho C_{p} u \cdot \Delta T=\nabla \cdot(k \nabla T)+Q
$$




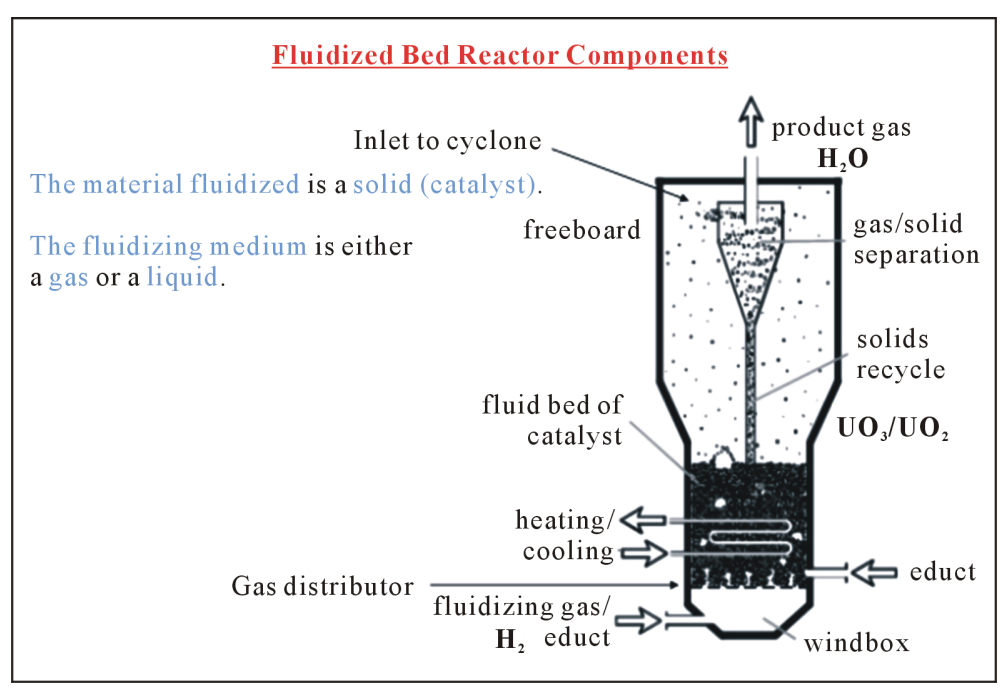

Figure 3. Conventional $\mathrm{UO}_{2}$ production reactor [9] [10].

$$
\frac{\mathrm{d} \rho}{\mathrm{d} t}+\rho \cdot(\nabla v)=0
$$

where $\rho$ : reduction gas density, $C_{p}$ : specific heat, $u$ : $\mathrm{H}_{2}$ flow velocity, $T$ : temperature, $k$ : conduction coefficient, $Q$ : source term, $t$ : time, $v$ : volume.

Solving this equation in the model will determine the temperature inside the $\mathrm{UO}_{3}$ reduction reactor and the generated heat by the exothermic reaction between the $\mathrm{UO}_{3}$ concentrate and the $\mathrm{H}_{2}$ reducing gas.

\subsection{Transport of Diluted Species}

Mass transport for dilute species is determined by the equation:

$$
\nabla \cdot\left(-D_{i} \nabla C_{i}\right)+u \cdot \nabla C_{i}=R_{i}
$$

where $D$ : Hydrogen diffusion coefficient, $C$ : Hydrogen concentration in the reduction gas, $u$ : Gas velocity flow, $R$ : Hydrogen consumption rate in the reaction zone.

This equation will determine the concentration profile of hydrogen and/or water displayed by the system in continuous operation type.

\section{Reactor Modeling [15]}

The reactor used in the development of experiences is shown in Figure 4.

This reactor is a tubular type, with input and output in conical shape. Its length is $1.66 \mathrm{~m}$. and it has an internal diameter of $4.5 \mathrm{~cm}$. The development of the experiences was performed by setting as parameters the initial temperature of both the gas and the reactor, which was between $400^{\circ} \mathrm{C}-500^{\circ} \mathrm{C}$ and initial hydrogen concentrations in the reducing gas: $0.25,0.5$ and $0.75 \mathrm{M}$. The flow feeding the reduction reactor was kept constant at 2.5 $\mathrm{L} / \mathrm{min}$. The input speed of this flow was $0.1 \mathrm{~m} / \mathrm{s}$, and the cross section of $1.5 \mathrm{~cm}$, so the feed flow regime was laminar.

To develop this model, the 3 transport phenomena mentioned before were occupied: momentum, heat and mass for dilute species. Working conditions are shown in Figure 5:

Figure 5 shows the considered parameters for the modeling: In the case of momentum transport, the reducing gas has inlet and outlet inside the reactor, and there is no slip flow on the walls. For heat transport, it is considered that the initial temperature for uranium conversion processes is $700 \mathrm{~K}$. The walls symbolize heat losses by natural convection, where this system was covered by a thermal jacket at $450 \mathrm{~K}$. The remaining heat will be generated by the exothermic reaction inside the vessel between $\mathrm{UO}_{3}$ and $\mathrm{H}_{2}$. Finally, for the transport of diluted species, reducing gas flow has the aforementioned initial hydrogen concentrations. A fraction of this gas is consumed by the $\mathrm{UO}_{3}$ vessel. The remaining hydrogen at the reactor outlet was burned to prevent gas leakage. In 


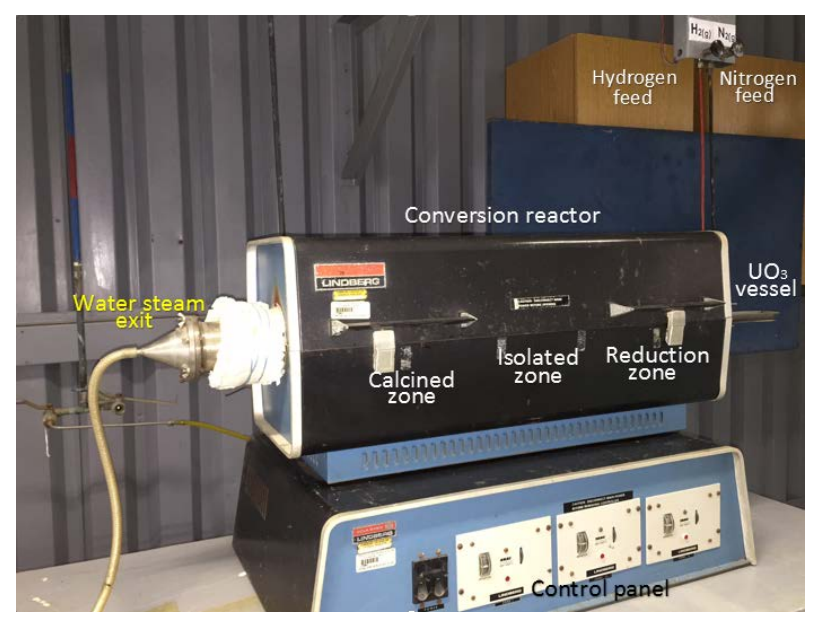

Figure 4. $\mathrm{UO}_{2}$ conversion reactor.

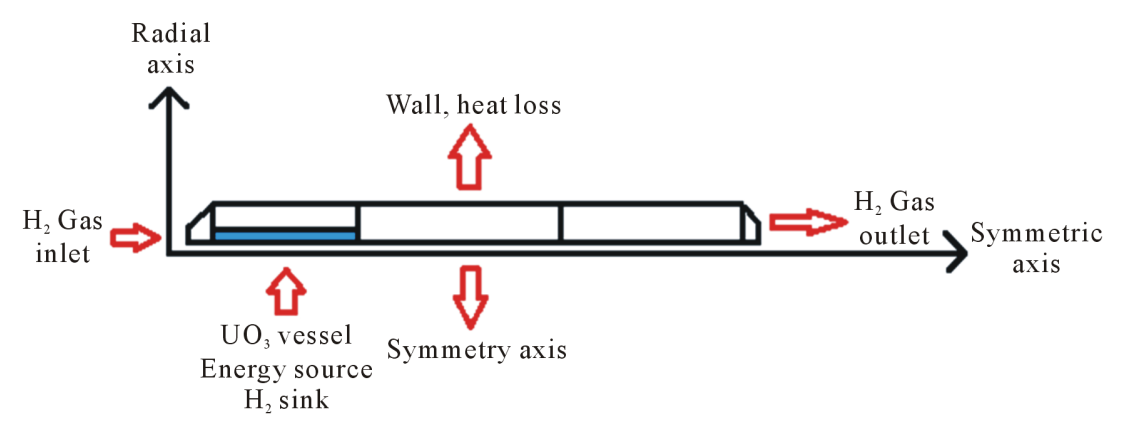

Figure 5. Working conditions for $\mathrm{UO}_{2}$ production.

order to simplify the development of the calculations, the model was proposed using as axial symmetry, in the bottom of Figure 5.

The equations used to the model development were obtained from previous studies [15]. In this work, the reduction kinetics of uranium trioxide was developed based on the formation of an intermediate compound, $\mathrm{U}_{3} \mathrm{O}_{8}$, according to the following reactions:

$$
\begin{gathered}
3 \mathrm{UO}_{3}+\mathrm{H}_{2} \rightarrow \mathrm{U}_{3} \mathrm{O}_{8}+\mathrm{H}_{2} \mathrm{O} \\
\mathrm{U}_{3} \mathrm{O}_{8}+2 \mathrm{H}_{2} \rightarrow 3 \mathrm{UO}_{2}+2 \mathrm{H}_{2} \mathrm{O} .
\end{gathered}
$$

The reduction rates for both equations were determined by using Arrhenius's Law, according to Equation (18):

$$
\frac{\partial y}{\partial t}=A * \exp \left(\frac{-E_{a}}{R * T}\right) * c H_{2}^{n}
$$

where $\frac{\partial y}{\partial t}: \mathrm{UO}_{3}$ reaction rate, $\mathrm{CH}_{2}$ : hydrogen concentration in the reducing gas, $n$ : reaction order for hydrogen concentration, $R$ : universal gas constant, $T$ : absolute temperature, $E_{a}$ : activation energy.

The corresponding reaction rates for Equations (17) and (18) are, respectively:

$$
\begin{gathered}
\frac{\partial y}{\partial t}=6.66 * 10^{5} * p H_{2}^{1.17} * \exp \left(\frac{-96799}{R * T}\right) \\
\frac{\partial y}{\partial t}=6.7 * 10^{13} * p H_{2}^{1.07} * \exp \left(\frac{-203693}{R * T}\right) .
\end{gathered}
$$

According to other authors [16], the conversion process is usually made from $\mathrm{U}_{3} \mathrm{O}_{8}$ compounds, as the uranium oxide with greater chemical stability. This implies that reaction (19) occurs uneventfully. Moreover, reac- 
tion rate (20) involves the formation of other intermediate oxides of uranium, such as $\mathrm{U}_{3} \mathrm{O}_{7}$ or $\mathrm{U}_{4} \mathrm{O}_{9}$, which, as already discussed in other studies [15] [16], decrease the overall speed of the process at temperatures above $700^{\circ} \mathrm{C}$. For this reason, reaction kinetics (21), which is the controlling step, will be used for modeling the reduction reactor.

\section{Results}

The obtained results were as follows:

According to Equations (12) and (13), it can be said that the progress of these reactions is quantified through water production. Figure 6 shows the $\mathrm{UO}_{3}$ reduction kinetics is so fast at these temperatures, almost no hydrogen exists in the vicinity of the vessel, where the reaction occurs. The following figure shows the linear profiles generating water into the reactor, along the axial symmetry.

Figure 7 shows that, for all hydrogen concentrations in the reducing gas, they are consumed almost entirely in the $\mathrm{UO}_{3}$ vessel.

However, the most important parameter for the development of experiences is the temperature profile along the reactor, and the exothermic peak reached by the system due to the release of reaction heat, as this defines the capacity of the system to work autonomously, without the need of additional energy. This profile is determined by the release of energy from the exothermic reaction between uranium oxides and hydrogen. The profiles obtained for the hydrogen concentrations in the reducing gas, are shown in Figure 8.

According to bibliographic data [15], the ideal temperature for the development of these experiences is $500^{\circ} \mathrm{C}$ - $600^{\circ} \mathrm{C}$. The objective of this result is to check whether the process can operate autonomously, keeping the temperature within this range. For this reason, the process must be performed at $0.5 \mathrm{M} \mathrm{H}_{2}$ concentrations to ensure this stationarity condition.

\section{Validation of Results}

The results of the experiments carried out in this reactor are shown in the following figure:

Figure 9 shows that $\mathrm{UO}_{3}$ reaction kinetics is virtually instantaneous in contact with the reducing $\mathrm{H}_{2}$ gas, since for temperatures of $500^{\circ} \mathrm{C}$ and $600^{\circ} \mathrm{C}$, the transformed fraction of $\mathrm{UO}_{3}$ to $\mathrm{UO}_{2}$ it is above $90 \%$.

In the case of temperature, the experimental exothermic peaks obtained are compared with the modeling system.

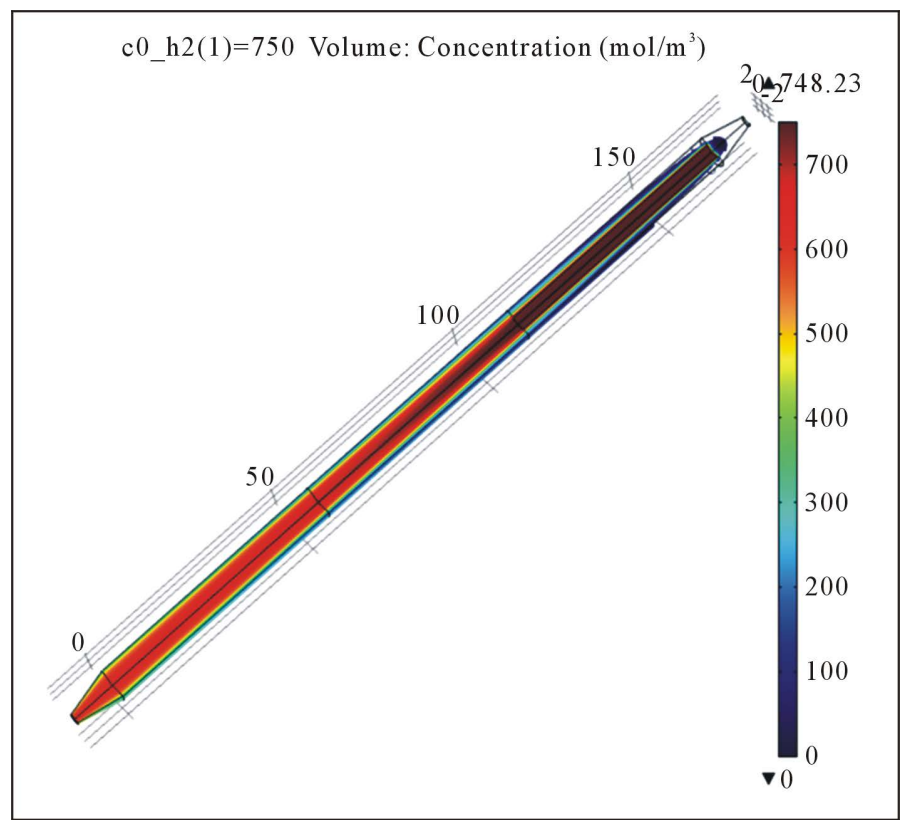

Figure 6. Volumetric concentration profile of water inside the reduction reactor. 


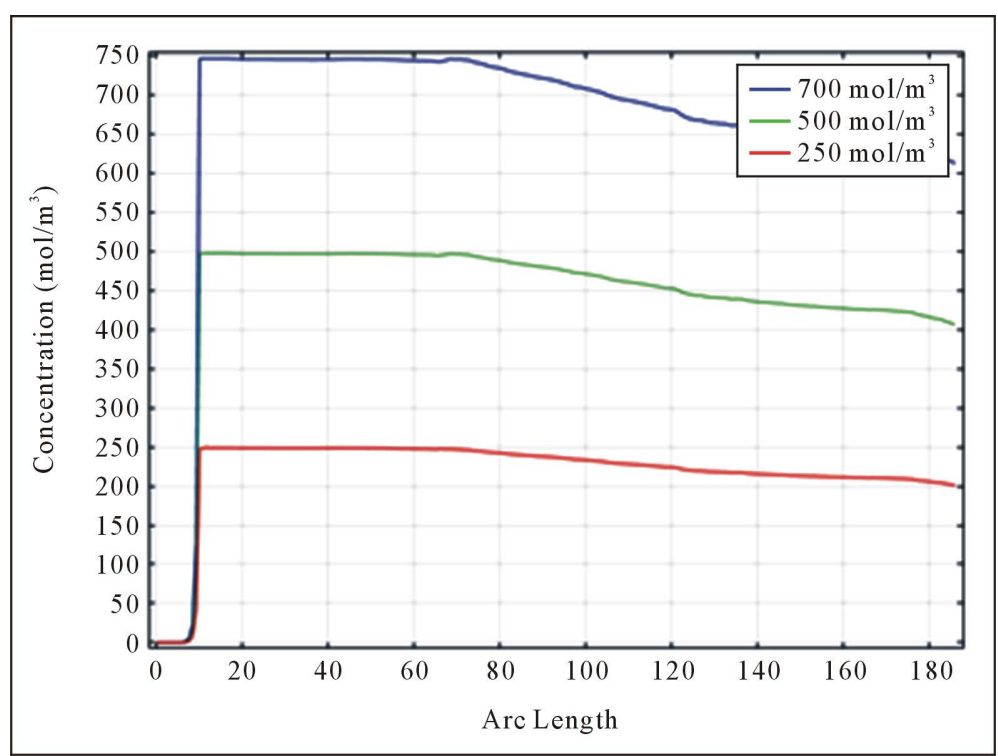

Figure 7. Water profile concentrations inside the reduction reactor.

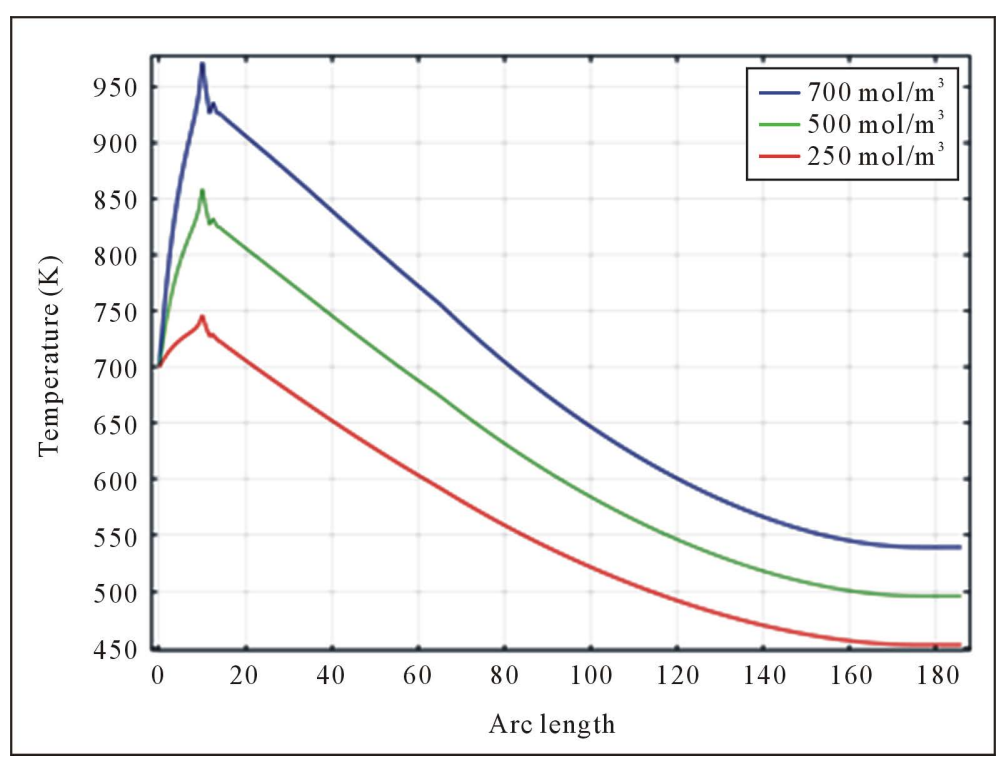

Figure 8. Temperature profile for the $\mathrm{UO}_{3}$ reduction reactor.

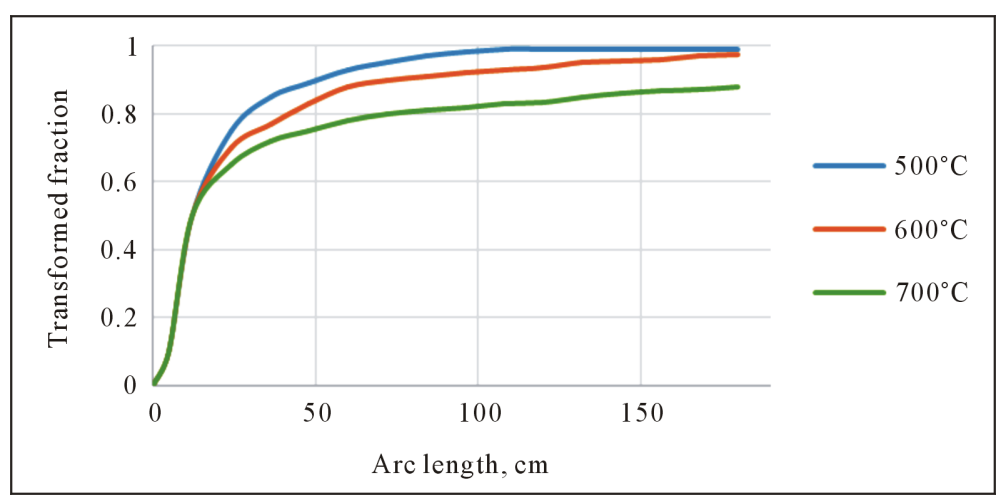

Figure 9. Reaction kinetics for uranium concentrates, at constant temperature. 
Table 1. Comparison between exothermic peaks.

\begin{tabular}{ccccc}
\hline Initial $\mathrm{T}^{\circ}(\mathrm{K})$ & {$\left[\mathrm{H}_{2}\right]\left(\mathrm{Mol} / \mathrm{m}^{3}\right)$} & $\begin{array}{c}\text { Exothermal peak }(\mathrm{K}) \\
\text { (experimental) }\end{array}$ & $\begin{array}{c}\text { Exothermal peak }(\mathrm{K}) \\
\text { (model) }\end{array}$ & Relative error (\%) \\
\hline 700 & 250 & 725 & 750 & 3.44 \\
700 & 500 & 805 & 860 & 6.83 \\
700 & 750 & 890 & 980 & 10 \\
\hline
\end{tabular}

Table 1 shows that the temperature system, operating continuously, can be predicted in an acceptable way using mathematical modeling techniques, since the data obtained for the proposed working conditions show relative errors of less than $10 \%$.

\section{Conclusions}

- From the previous data of $\mathrm{UO}_{2}$ production, it is possible to predict the reduction of $\mathrm{UO}_{3}$ compounds with hydrogen using mathematical modeling techniques.

- The fluidized bed reactors can be monitored effectively with the gaseous products, which means that it is not necessary to manipulate the $\mathrm{UO}_{3}$ vessel. This fact allows the safety during the data collection.

- For the studied kinetic parameters, the $\mathrm{UO}_{3}$ reduction reactions occur almost instantly, as the results show a hydrogen conversion to water almost completely.

- The condition that allows continuous operation for the reduction reactor is feeding with reducing gas at $0.5 \mathrm{M}$ $\mathrm{H}_{2}$.

- The temperature profiles and relative errors allowed to conclude that the reduction of $\mathrm{U}_{3} \mathrm{O}_{8}$ compounds to $\mathrm{UO}_{2}$ provided the required energy to maintain the working temperature in the required ranges.

\section{Acknowledgements}

The Chilean Nuclear Energy Commission acknowledges the assistance provided by University of Santiago, Chile, in the use and license of computer software COMSOL Multiphysics v4.3b, “CFD Module User's Guide”, Modeling Single Phase Flow, Page 27-144. License Number: 2079130, Host ID: 5c260a04780b, 1.998-2.103.

\section{References}

[1] http://www.world-nuclear.org/information-library/nuclear-fuel-cycle/nuclear-power-reactors/nuclear-power-reactors.as px

[2] http://www.areva.com/EN/operations-757/conversion-the-fluorination-of-uranium-in-2-stages.html

[3] (1999) Minimization of Waste from Uranium Purification, Enrichment and Fuel Fabrication. IAEA-TECDOC-1115, IAEA, Vienna.

[4] https://geoinfo.nmt.edu/resources/uranium/enrichment.html

[5] http://web.ead.anl.gov/uranium/guide/depletedu/enrich/

[6] Johnson, T. (2010) Uranium Mining, Milling, Enrichment and Fuel Fabrication in the United States. Colorado State University.

[7] Cardelli, F. (2000) Materials Handbook: A Concise Desktop Reference. Springer Verlag, London. http://dx.doi.org/10.1007/978-1-4471-3648-4

[8] Nuclear Fuel Cycle, Information System. A Directory of Nuclear Fuel Cycle Facilities, 2009 Edition.

[9] Cameron, I. (2007) Nuclear Fission Reactors. Plenium Press, New York.

[10] LinkenIN Slide Share (2013) Introduction to Fluidized Beds. Chemical Reaction Engineering Laboratory, School of Engineering and Applied Science, Washington University, St. Louis.

[11] (1986) Advances in Uranium Refining and Conversion. International Atomic Energy Agency, Vienna.

[12] Sidorov, E.V. and Sofronov, V.L. (2011) Investigation of the Kinetics of $\mathrm{U}_{3} \mathrm{O}_{8}$ Reduction by Hydrogen and Ammonia under Non-Isothermal Conditions.

[13] Harrington, Ch. and Ruehle, A. (1959) Uranium Production Technology. Mallinckrodt Chemical Works, St. Louis, 
Missouri.

[14] Gaskell, D. (1990) An Introduction to Transport Phenomena in Materials Engineering. 2nd Edition, Momentum Press, New York.

[15] Alfaro, P.O., Torres, J.H. and Thiele, F.P. (2015) Reduction Kinetics of Uranium Trioxide to Uranium Dioxide Using Hydrogen. World Journal of Nuclear Science and Technology, 5, 149-156. http://dx.doi.org/10.4236/wjnst.2015.53015

[16] Razdan, M. (2013) Electrochemical and Surface Compositional Studies on Uranium Dioxide. Electronic Thesis and Dissertation, Repository, Paper 1740.

\section{Submit or recommend next manuscript to SCIRP and we will provide best service for you:}

Accepting pre-submission inquiries through Email, Facebook, Linkedin, Twitter, etc A wide selection of journals (inclusive of 9 subjects, more than 200 journals)

Providing a 24-hour high-quality service

User-friendly online submission system

Fair and swift peer-review system

Efficient typesetting and proofreading procedure

Display of the result of downloads and visits, as well as the number of cited articles

Maximum dissemination of your research work

Submit your manuscript at: http://papersubmission.scirp.org/ 